\title{
NATO's New Strategic Concept: Non-Traditional Threats and Bridging Military Capability Gaps
}

\author{
By Muhidin Dzambic ${ }^{1}$
}

\section{Introduction: The Utility of a Strategic Concept}

At the Lisbon Summit in November 2010, NATO leaders adopted a new Strategic Concept (SC) in order to provide the Alliance with strategic guidance over the next decade. The goal of this essay is to identify and examine the gaps between SC statements, goals, and plans and the military capabilities of NATO members concerning today's environment of defense budget cutting. In particular, this article will focus on military roles and capabilities for tackling issues such as terrorism, cyber attacks, and energy security, which as non-military threats require a more comprehensive approach.

The Strategic Concept is an official and comprehensive policy document that outlines NATO's enduring purpose, nature, and the fundamental security tasks of the Alliance. It characterizes the central features of the new security environment, specifies the elements of the Alliance's approach to security, and provides guidelines for the further adaptation of its military forces in order to address new challenges. The new SC is concise, concrete, and public, and its broader purpose is to explain the Alliance's political objectives and vision for the future decade. ${ }^{2}$ NATO's Security Concepts are documents intended to give political guidance on NATO's role, missions, and objectives. These SCs are accompanied by documents prepared by the Alliance's Military Committee (AMC) on the military assets, capabilities, and structures necessary for carrying out the strategic objectives identified by the political authorities of the Alliance, as represented by the North Atlantic Council (NAC). ${ }^{3}$

According to the previous two explanations, the "Strategic Concept" can be defined as a "grand strategy" document in terms of political and military guidance for

1 Lt. Col. Muhidin Dzambic received an M.A. from the European Institute of the University of Geneva in the field of International and European Security. This essay represents a part of the research he completed for his master's thesis. The author is an officer working at the Ministry of Defense in Bosnia and Herzegovina. The views expressed in this paper are his own and do not reflect the position of the MoD of Bosnia and Herzegovina.

2 NATO, "New Strategic Concept FAQs," available at http://www.nato.int/strategic-concept/strategic-concept-faq.html.

3 Defense Committee of the Western European Union, The NATO Strategic Concept and Evolution of NATO (Paris: Assembly of the Western European Union, 2 December 2010, Report A/2085), 5. 
the Alliance itself and for all twenty-eight members. It represents the Alliance's strategic adjustment based on the complex and evolving regional and global security environment and challenges characterized by new non-traditional and non-military threats, which are very often unpredictable. It outlines NATO's purpose to safeguard the security of its members by using political and military means. The SC sets out the political and military path for the Alliance to follow in order to achieve its stated objectives. Previously, the function of the SCs has been to confirm past decisions and today's practices, provide strategic guidance and direction for the future, and constitute an important tool of public diplomacy. The new SC summarized and formalized the string of ministerial communiqués and lesser decisions that have emerged since the last SC. ${ }^{4}$

The first decade of the twenty-first century has witnessed the rising strategic importance of terrorism (following the attacks of 9/11 and the so-called Global War on Terrorism), an increased dependence on cyberspace, and greater interdependence between consumers and producers of energy. At the NATO Summit in Strasbourg/ Kehl in April 2009, NATO leaders decided to update the Strategic Concept. The main idea was that the new document had to define NATO's strategy for the post-9/11 era, which is characterized by non-traditional and unconventional threats. As Karl-Heinz Kamp noted:

Some may argue that NATO already has a viable strategy. Indeed, NATO already has a Strategic Concept, but this document was agreed upon in 1999-in the midst of the Kosovo war. That was before NATO took on a new type of peace enforcement in the Balkans, before September 11 altered threat perceptions and the political priorities of the entire Western world, before NATO assumed a crucial role in Afghanistan, before the Iraq war led to a fundamental discussion on the role of "preemptive" defense, and before NATO took in seven new members, a major increase which has led to severe problems of assimilation. ${ }^{5}$

For the former NATO Secretary-General Jaap de Hoop Scheffer, the key reason for the revision of the SC has been mostly about the capability, effectiveness, and efficiency of the Alliance: "The burdens on NATO are greater today than ever before and this makes it even more urgent that we have a clear strategic vision, clear priorities, and above all, a clear sense of the resources that we need to be successful." ${ }^{\prime 6}$ The

$4 \quad$ Jens Ringsmose and Sten Rynning, Come Home, NATO? The Atlantic Alliance's New Strategic Concept (Copenhagen: Danish Institute for International Studies, 2007, DIIS report No. 4), 7.

5 Karl-Heinz Kamp, "Bush and the Future of NATO," Defense News (21 February 2005).

6 Jaap de Hoop Scheffer, Secretary-General of NATO, "Beyond the Bucharest Summit," speech delivered in Brussels, 12 March 2008; available at http://www.nato.int/ docu/speech/2008/s080315a.html. 
present Secretary-General, Anders Fogh Rasmussen echoed this sentiment, stating "NATO is an unparalleled community of freedom, security and shared values. But the world is changing. We face new threats and new challenges. And this SC will ensure that NATO remains as effective as ever in defending our peace, our security and our prosperity." In the contemporary world, when the security environment and challenges are changing faster than ever before, this Concept cannot offer an "allinclusive" package for particular crises and threats. Given the pace of change in the geostrategic environment, the Alliance has committed to regularly updating the SC at its following summits.

There is no clear method by which the Alliance goes about the process of elaborating a new SC. NATO has used several templates or approaches in the past. This time, a group of experts led by former U.S. Secretary of State Madeleine Albright drafted a report to help the SG prepare the Concept. Prior to the summit, Secretary-General Rasmussen personally prepared the draft of the SC. This marked the first time that a secretary-general specifically took the responsibility to prepare a draft of the Concept himself. However, the process of drafting the Concept has been more transparent and public than before, including discussions and consultations with all NATO members.

According to the new SC, there are three core tasks for the Alliance: collective defense, crisis management, and cooperative security. ${ }^{8}$ The new SC stresses NATO's need to adopt modern defense means against emerging threats. A core element of the new SC is the development of a capability for defense against ballistic missile attacks, in order to protect the troops and populations of member states. The Alliance also seeks a balance in response between conventional threats and emerging unconventional and non-military threats. In addition, it has begun to initiate an enormous transformation, the biggest one in its existence, with downsizing a number of NATO HQs and agencies.

The modern era poses several "new" and growing non-traditional and non-military security threats and challenges that threaten state and international security. If we take into account some of them - such as transnational terrorism, cyber attacks, and threats to energy security, along with developments in the world that are related to these three threats - we see that they are constantly growing in the globalized world. These threats, together with several other non-conventional threats, are the decisive factors for security in the world today. Therefore, most security organizations at the national and international level take measures to cope with these global challenges.

7 Anders Fogh Rasmussen, Secretary-General of NATO, interview in Lisbon, 19 November 2010.

8 North Atlantic Council, Strategic Concept-Active Engagement, Modern Defence (Lisbon: NATO, 19 November 2010), 4. 
It follows that it is of crucial importance that NATO, as the most successful military alliance in history, transform its capabilities to effectively confront these threats.

In the past decade, NATO has made significant steps in defining these threats, elaborating doctrines, and adapting and creating a new military structure. However, in a globalized world, events and the development of new ways and methods of attack require an adequate response. That is why NATO's new SC adopted new measures and targets to successfully address these threats in the near future. Those three threats are closely linked, and as such constitute an even greater danger. To achieve success in the fight against these threats, it is necessary to analyze them together and fight against them simultaneously. This is a big challenge for the Alliance, which by its nature is more or less a political-military organization. It is therefore of interest to analyze and see how NATO would implement the agreed-upon activities and encourage the ultimate goal. The recent establishment of NATO's Emerging Security Challenges Division (ESCD) in August 2010, in order to deal with emerging non-traditional threats and challenges including terrorism, cyber defense, and energy security, is a clear signal that the Alliance realized how important those issues are. ${ }^{9}$

The main focus of this article is to identify and assess how the military should transform and adapt in order to address the challenges of terrorism, cyber attacks, and issues of energy security that are highlighted in the new SC. The essay explores three key questions:

-What political guidance does the Strategic Concept give with regard to terrorism, cyber security, and energy security?

- What are the implications of this guidance regarding the development of appropriate military capabilities for addressing those three strategic challenges?

- How likely is NATO to develop appropriate military capabilities to address the threats?

Alliance theory suggests that there are several necessary preconditions for security alliances. Those preconditions are a compatible view on threats, shared interests, and similarities in approach, capacities, capabilities, and political will. All of those conditions do not necessarily have to be identical for each member, but there must be an acceptable level of agreement, compatibility, applicability, and shared interest, as well as the will in order to have some level of effectiveness and cohesion. According

9 NATO, "New NATO Division to Deal with Emerging Security Challenges," 1; available at http://www.nato.int/cps/en/SID-6E509263-1BF11962/natolive/news_65107. $\mathrm{htm}$ ?selectedLocale=en. 
to Stephen Walt, "Efforts to attract allies in the absence of compatible political goals fail; client states serve the patron's interests only when the actions serve their own interests as well. In general, the existence of a threat or hostile power is a necessary condition for developing a collective security alliance, since a collective security [Author: missing word?] is one type of alliance, as the balance of threat theory demonstrates. ${ }^{10}$ Alliance theory suggests, as the balance of threat theory argues, that great powers can develop their power and form an alliance with other states in order to balance against potential aggressors when they perceive external threats.

According to Martin Wight, the function of an alliance is to "reinforce the security of the allies or to promote their interests in the external world." facing a stronger enemy unilaterally decide to cooperate with other states in the same situation in order to increase their security by massing their capabilities against a common enemy. ${ }^{12}$ In other words, when facing an external threat, states join an alliance to enhance their defense capabilities against a common threat. According to the former NATO Secretary-General Jaap de Hoop Scheffer, "NATO is a permanent alliance. It was never just a military alliance to deal with a singular threat. NATO gave a politically, economically and morally devastated Europe the necessary reassurance to cope with the many challenges that it faced. There is a difference between NATO and traditional military alliances: NATO is a framework for political change-indeed, it is an instrument to shape change." ${ }^{\prime 13}$ The Soviet threat no longer exists, but NATO has enlarged its membership, expanded its mission, and invested in new capabilities. NATO has outlasted the pole of power it was first created to balance..$^{14}$ In other words, NATO has adapted itself to tackle contemporary non-military threats and challenges, but NATO's core function has not changed. The Alliance's major purpose is still the collective defense of member states.

If alliance theory holds true, then this research question is of interest because it identifies the limits of existing capabilities to adapt to contemporary security threats and the need therefore to develop new capabilities. Does a consensus emerge as to the necessary steps that militaries must take to adapt, or does ambiguity characterize the military response? What are the trade-offs and dilemmas that can be identified

10 Stephen Walt, The Origins of Alliances (New York: Cornell University Press, 1987), 21-22.

11 Martin Wight, Power Politics (New York: Holmes \& Maier, 1978), 122.

12 George Liska, Nations in Alliance. The Limits of Interdependence (Baltimore: Johns Hopkins University Press, 1962), 13.

13 Jaap de Hoop Scheffer, Secretary-General of NATO, speech at Institute for National Security Studies and Atlantic Forum of Israel, Tel Aviv, 11 January 2009; available at http:// www.nato.int/cps/en/SID-84899E77-187EABEE/natolive/opinions_49673.htm.

14 Jonathan Sireci and Damon Coletta, "NATO's Realist Foundation, Enduring without an Enemy," Perspectives, Central European Review of International Affairs 17:157 (Summer 2009); 57; available at http://infoalert.usembassy.de/trans/f13_409.htm. 
and that inform the debates and discussions in this regard? Do these debates give us a good insight into the utility of NATO over the next decade?

To that end, the next section of this essay starts with the first case study: terrorism. What military capabilities need to be improved and developed in order to face this threat, and is it achievable? The chapter examines the transformation and adaptation of the military in order to be effective and efficient in fighting terrorism. The second case study examines cyber attacks, one of the most severe threats according to the new SC. NATO has had some success in the field of cyber defense, but it is far from enough. One of the priorities for the Alliance is to speed up the process of adapting and developing new capabilities that are able to protect all NATO members. The third case study focuses on energy security. Ensuring a stable energy supply and a diverse range of resources remain of critical importance to NATO. This is an ambiguous task for the military to adapt itself to tackle. The chapter examines NATO's dependence on various supplies of energy and its role as a provider of energy security to the member states. The following section assesses the findings of each of these case studies, and attempts to characterize the wider implications of NATO's military capability transformation for the Alliance, with regard to what will be achieved in the next period in terms of transformation and adaptation of the military, having in mind that defense budgets of the member countries are being cut due to the global economic crisis. On this basis the article closes with key conclusions.

\section{Tackling Terrorism}

In the last ten years, transnational terrorism has become the greatest danger to the member states of NATO, exerting a decisive influence on the development and engagement of the Alliance. Since $9 / 11$ NATO has been involved in a constant process of adaptation and development of new doctrine and capacity in order to successfully respond to this emerging phenomenon. At the last summit in Lisbon, terrorism as a serious threat was at the top of the agenda of the Alliance.

What was agreed in Lisbon? According to the Lisbon Summit declaration, "Terrorism poses a direct threat to the security of the citizens of NATO countries, and to international stability and prosperity more broadly." ${ }^{15}$ In addition, "We will enhance the capacity to detect and defend against international terrorism, including through enhanced analysis of the threat, more consultations with our partners, and the development of appropriate military capabilities, including helping train local forces to fight terrorism themselves." ${ }^{\prime \prime}$ Moreover, "All acts of terrorism are criminal and unjustifiable, irrespective of their motivations or manifestations. In accordance with the

\footnotetext{
North Atlantic Council, Strategic Concept, 3.

16 Ibid., 5.
} 
SC, we will continue to enhance both the political and the military aspects of NATO's contribution to deter, defend, disrupt and protect against this threat including through advanced technologies and greater information and intelligence sharing." 17

What steps towards addressing this threat were undertaken prior to the Lisbon Summit? Even before the terrorist attacks of 11 September 2001, it was already clear that being ahead in the technological and intelligence fields was no guarantee of immunity from attack. However, the Al Qaeda attack on the U.S. demonstrated that even a superpower can fall victim to attack. After 9/11, U.S. President George W. Bush declared a "war on terror" in order to destroy Al Qaeda and the Taliban in Afghanistan, and to therefore prevent any possibility for another attack on the U.S. ${ }^{18}$ The terrorist attacks caught NATO unprepared. On 12 September 2001, the NAC invoked Article $\mathrm{V}$ of the North Atlantic Treaty, and fighting terrorism became a priority for NATO. As a consequence, NATO launched its first official counter-terrorism campaign, Operation Active Endeavour (OAE), which included the protection of non-military vessels in the Mediterranean and through the Straits of Gibraltar. Thus, it was necessary for NATO to have adequate concepts, policies, and doctrines for defense against terrorism.

The Military Concept (MC) for defense against terrorism was developed by the NATO military authorities and approved by the NAC at the Prague Summit on 21 November 2002. The Military Concept identifies four different roles of military operations for defense against terrorism. In each of the four roles, force protection is an essential consideration. The four roles are:

- Anti-terrorism, i.e., defensive measures against terrorism

- Management of the consequences of a terrorist attack

- Offensive counter-terrorism operations

- Military cooperation, particularly intelligence sharing.

Each of these four roles is elaborated in further detail in order to outline its purpose to serve as guidance for NATO military forces during the adaptation of existing and development of required capabilities. This identified many essential capabilities such as better deployability, readiness, effective intelligence and engagement in order to reduce the risk of collateral damage, enhance force protection, and provide CBRN defense. In addition, it identifies procedures that need to be developed, such as iden-

17 NATO, Lisbon Summit Declaration (Lisbon: NATO, 20 November 2010), 10; available at http://www.nato.int/cps/en/natolive/official_texts_68828.htm?selectedLocale=en.

18 George W. Bush, speech to a joint session of the U.S. Congress, 20 September 2001; available at http://middleeast.about.com/od/usmideastpolicy/a/bush-war-on-terrorspeech.htm. 
tifying Alliance vulnerabilities and how to protect them, developing international strategy, providing support to civil authorities, reducing the availability of WMD, and making decisions effectively and quickly. The main conclusion is that NATO must be prepared to conduct military operations to engage terrorist groups and their capabilities, as and where required. ${ }^{19}$ At the Prague Summit, NATO adopted a Partnership Action Plan against Terrorism (PAP-T), which is the policy for the joint effort in fighting terrorism. The focus is on intelligence and cooperation, especially in counter-terrorism training and exercises, and the development of capabilities for defense.

The Military Concept set forth quite an ambitious goal, but after the attacks on 9/11, nothing less from NATO was expected. Terrorism has been declared the main threat to collective security, at least in NATO's documents. ${ }^{20}$

In 2003, NATO HQ established the Terrorist Threat Intelligence Unit (TTIU) in order to enhance intelligence sharing and information assessments. The most important organizational change within NATO's anti-terrorism military structure was the creation of the NATO Response Force (NRF) in 2003. ${ }^{21}$ By late 2004, this formation reached an operational level of about 9000 personnel. The terrorist attacks in Madrid (2004) and London (2005) have further strengthened NATO's commitment to fighting terrorism. In the wake of these attacks, NATO adopted the Comprehensive Political Guidance (CPG) at the Riga Summit in 2006. It provides the framework and political direction for the process of NATO transformation, setting out priorities concerning capabilities, planning, and intelligence. In this document, terrorism is identified as one of the principal threats to NATO. Currently, counterterrorism is a key focus for Alliance cooperation with many partners, including Russia.

The Program of Work for Defense against Terrorism was the next specific initiative to improve Alliance capabilities for countering terrorism. It was approved at the Istanbul Summit. The main goal is to equip the armed forces and develop technologies to prevent terrorist action against civilian populations, infrastructure, and military targets. This program is unique because some of the members are developing different capabilities, such as large aircraft survivability, protection of helicopters, countering improvised explosive devices, precision airdrop for special operations

19 NATO, "NATO's Military Concept Against Terrorism," 2; available at http://www.nato. int/ims/docu/terrorism.htm.

20 Rafael L. Bardaji, "Prospects for a New NATO Strategic Concept," Strategic Studies Group (10 October 2007), 3; available at http://www.isn.ethz.ch/isn/Communities-andPartners/Partners/Detail/?lng=en\&id= 53876.

21 NATO, The Prague Summit and NATO's Transformation (Brussels: NATO Public Diplomacy Division, 2003), 27; available at http://www.nato.int/docu/rdr-gde-prg/rdr-gde-prgeng.pdf. 
forces, intelligence, reconnaissance, surveillance, target acquisition of terrorists, defense against mortar attacks, and critical infrastructure protection. ${ }^{22}$

Given the steps taken, what has been achieved? While NATO official documents are coherent and comprehensive with regard to methods to be used to address terrorism, the reality on the ground in Afghanistan is different. Expectations of military victory against terrorists still appear to figure highly in Alliance thinking, and the apportioning of counter-terrorism resources has reflected that flawed approach. However, research by the RAND Corporation into the case histories of 648 terrorist organizations that carried out attacks between 1968 and 2006 found that only 7 percent were successfully eliminated through direct military force. This is in contrast to 43 percent that dropped their violent activities after some form of political accommodation and 40 percent who were broken up successfully through some combination of local community policing, infiltration, and prosecution. NATO counterterrorism policy needs to focus on international cooperation to improve the intelligence base, strengthen civilian law enforcement capabilities, restrict terrorist access to funds and weapons, and reduce the root causes driving people to radical violence. ${ }^{23}$

Analyzing NATO's achievements in fighting terrorism since 2001, we can say that their efforts have resulted in preventing Al Qaeda from conducting terrorist actions in the U.S. and Western Europe. During this period Al Qaeda only made a few attempts at attack, with limited consequence. Many planned actions have been prevented, and terrorists were arrested or killed. No one knows the exact number of actions that have been prevented due to enhanced counterterrorist capabilities. Improvements in fighting terrorism over the last ten years on the Western countries' soil are obvious and evident. But what is the root of the Al Qaeda organization and insurgent movement in Afghanistan? The main task was to arrest or kill Osama Bin Laden, it took nearly ten years before a team of U.S. Navy SEALs achieved that goal on 1 May 2011. The main problem remains how to eradicate terrorist organizations and destroy their leaders in Afghanistan using military force.

The attacks on the United States on 11 September 2001 were treated by NATO under Article $\mathrm{V}$ of the Washington Treaty, which stipulates that an armed attack against one or several members shall be considered an attack against all. ${ }^{24}$ At the beginning, NATO succeeded in creating a strong coalition, and all major members agreed to join

22 NATO, "Defense Against Terrorist Program," available at http://www.nato.int/cps/en/natolive/topics_50313.htm.

23 NATO WATCH, "NATO Reform Lite: An Evaluation of the Lisbon Summit," Briefing Paper, No.14 (Lisbon: NATO WATCH, 26 November 2010), 13; www.ata-sec.org/docs/ doc.../64-an-evaluation-of-the-lisbon-summit-part-i.

24 Lord Robertson, Secretary-General of NATO, speech at NATO Headquarters, 2 October 2001. Accessed available at http://www.nato.int/docu/pr/2001/p01-138e.htm. 
the "war on terrorism," most with significant domestic public support. They pushed the Taliban from power and arrested and killed a number of terrorist leaders and fighters. In this period, few could have predicted the huge challenges that coalition forces would have to face, as well as the costs and time required for mission accomplishment.

At the very beginning, the Alliance identified that military operations are not enough to defeat terrorism. The military must coordinate diplomatic, political, and civilian activities with many non-military skills and efforts. To that end, as we read above, the Alliance issued a number of documents in order to coordinate activities, especially in the field of the Comprehensive Approach in Afghanistan, but also in Pakistan. But it has not been an easy task to achieve these goals, concerning the characteristics and features of terrorist movements in Afghanistan and Pakistan, which are unique in many respects.

Regardless of a number of successful operations in Afghanistan that have diminished terrorist and insurgent capabilities, some of the military actions and activities on the ground have had counterproductive effects and consequences with a huge impact on ongoing and future operations in Afghanistan. One of the most oft-repeated terms in the news from Afghanistan during the last two years has been "collateral damage." Many civilians, including children and women, have been killed by coalition forces due to the lack of coordination between troops and intelligence. These negative outcomes were exactly what Al Qaeda desperately needed, and they used them against ISAF in aggressive propaganda campaigns to influence the Afghan people. In these circumstances, NATO troops failed to separate terrorists and the population and diminish the influence of terrorists on the population. As one NATO observer has noted,

NATO's specialized counter-insurgency and counter-terrorism forces need to have clearly defined doctrines, rules of deployment and engagement, and effective parliamentary oversight. In particular, the possible use of NATO air power or Special Operation Forces (SOF) to target specific terrorist training camps remains an option that would need to be used sparingly and proportionately. As one analyst rightly concludes, the military is not a surgical tool of political engineering and assuming an expensive role as world police gifts propaganda opportunities to extremists - and the ultimate logic of such an approach is endless war. ${ }^{25}$

The real military power of NATO lies in the military power of each member of the Alliance, and thus directly depends on the military capabilities of the individual states. That is the reason why the most important goal for U.S. leaders since 2006 has been to convince France, Great Britain, and Germany to increase their levels of defense spending. It is obviously one of the crucial preconditions for improving

25 NATO WATCH, “An Evaluation of the Lisbon Summit,” 13. 
counterterrorist capabilities. NATO members agreed that defense spending should be 2 percent of GDP, but only six states in Europe met that criterion. The percentage itself is relevant for assessment, but it is more important to ensure that the money is spent in the way it was agreed within NATO, on the transformation of forces.

As a logical consequence of the current global financial crisis, it is reasonable to expect a new decline in defense spending, especially in Western Europe. It is still difficult to gather political support for providing sufficient resources for military operations. ${ }^{26}$ However, these new capabilities are directly connected with ongoing and future NATO operations and spending in the field of strategic airlift and new assets for counterterrorism missions.

The Comprehensive Approach, with its combination of non-military and military efforts, is the only way of achieving success. Military spending by European Allies is not sufficient to meet the full range of Alliance responsibilities at an affordable cost. It is a necessity for NATO to meet the conventional defense needs, such as achieving its deployability and interoperability goals; broaden the role of the NATO NRF; improve C4ISR; strengthen its SOF capabilities; and improve the contribution of the ACT as the agent for the military transformation of NATO's forces. These must be underpinned by reform and efficiency measures including common funding, development of truly multinational formations, and more NATO common capabilities. NATO-EU cooperation in capability development and planning is of the essence. ${ }^{27}$

This leads to the conclusion that NATO leaders still see military power as a decisive point in fighting terrorists and insurgencies in Afghanistan. It is not realistic to expect a military victory against terrorists without improvements on the political, diplomatic, and economic fields within the highly divided Afghan society. Indeed, "Unrealistic expectations of military victory against non-state actors still appear to figure highly in Alliance thinking. NATO's specialized counter-insurgency and counter-terrorism forces need to have clearly defined doctrines, rules of deployment and engagement, and effective parliamentary oversight. In particular, the possible use of NATO air power or SOF to target specific terrorist training camps remains an option that would need to be used sparingly and proportionately." ${ }^{28}$

NATO has focused on terrorism on the strategic policy level. Developing and articulating NATO policy for fighting terrorism has also included active interactions and consultations with partners and other IOs, especially regarding the issues of de-

26 Karl-Heinz Kamp, “The Way to NATO's New Strategic Concept," NATO Defense College Research Paper No. 4 (Rome: NATO Defense College, June 2009), 4.

27 NATO, NATO 2020: Assured Security, Dynamic Engagement, Analysis and recommendations of the group of experts on a new strategic concept for NATO (Brussels: NATO, 17 May 2010), 39.

28 NATO WATCH, "An Evaluation of the Lisbon Summit," 13. 
velopment of new doctrine, a military concept for defense against terrorism, new capabilities, increased intelligence sharing, mutual cooperation, civil emergency planning efforts, and, of course, Operation Active Endeavor, which is a terrorism-related operation.

\section{Cyber Attacks}

The 2010 Strategic Concept stresses the need for NATO to address cyber security as one of the most challenging priority issues in the new millennium. Rapid evolution in the cyber field makes the protection of NATO's information and communication systems a critical task. In Lisbon, NATO issued political guidance on cyber defense and requested a detailed review of current achievements and developments in the form of an in-depth cyber defense policy by June $2011 .{ }^{29}$ The Alliance's activities are focused on how to develop centralized cyber protection in order to defend its own systems and assist member states in defending their informatics networks.

What was agreed in Lisbon? According to the Lisbon declaration,

Cyber attacks are becoming more frequent and more costly in the damage that they inflict on government administrations, economies and potentially also transportation and supply networks and other critical infrastructure; they can reach a threshold that threatens national and Euro-Atlantic prosperity, security and stability. Foreign militaries and intelligence services, organised criminals, terrorist and/or extremist groups can each be the source of such attacks. We will develop further our ability to prevent, detect, defend against and recovering from cyber attacks, including by using the NATO planning process to enhance and coordinate national cyber-defence capabilities, bringing all NATO bodies under centralized cyber protection, and better integrating NATO cyber awareness, warning and response with member nations. ${ }^{30}$

Indeed, the threat from cyber attacks is rapidly increasing, and it is crucial for the Alliance to make sure that command and control networks are protected. One serious interruption could cause unprecedented consequences for NATO's troops on the ground.

According to the experts' group report on the new SC,

NATO must accelerate efforts to respond to the danger of cyber attacks by protecting its own communications and command systems, helping Allies to improve their ability to prevent and recover from attacks, and developing an array of cyber

\footnotetext{
NATO, Lisbon Summit Declaration, 11.

30 North Atlantic Council, Strategic Concept, 4-5.
} 
defence capabilities aimed at effective detection and deterrence. The next significant attack on the Alliance may well come through a fibre optic cable. Already, cyber attacks against NATO systems occur frequently, but most often below the threshold of political concern. However, the risk of a large-scale attack on NATO's command and control systems or energy grids could readily warrant consultations under Article 4 and could possibly lead to collective defence measures under Article 5. ${ }^{31}$

In other words, NATO needs to be more effective in order to prevent massive cyber penetration into vital computer networks and information systems in member states as well as NATO's own command and control networks. Such an effort will require a common response from all member states and from NATO as a whole. It is an ambitious goal if we take into account the vulnerabilities of those networks, which have been evident since 1999. According to NATO's new SC, in case of serious cyber attack on any member state, the Alliance will have consultation under Article IV to respond to such an attack.

Cyber attack is a relatively new phenomenon, and there have been some recent examples of being used as an asset by one nation against another. These include a Chinese hacker targeting U.S. official Web sites during the NATO intervention in Serbia in 1999; the "Estonian case" in 2007, when the government, banks, and other institutions were attacked by hackers; a series of cyber attacks in Georgia prior to the Russian military action in August 2008; and similar attacks in Kyrgyzstan in 2010 ahead of the "April Events." Cyber warfare is the subject of considerable attention in the media and in policy realms together with cyber threats, cyber attacks, cyber terrorism, and cyber weapons. It is important for NATO to understand what "cyber war" and related terms mean, and what the implications for NATO are. The main challenge of discussing cyber attack is answering the question: when does a cyber attack become an act of war or a crime? $?^{32}$

Prior to the Lisbon Summit, what steps had been taken to address this threat? NATO continuously developed the protection of its communication and information systems. These capabilities to assist nations to protect their networks represent the implementation of NATO's current policy on cyber defense, which was approved by NATO in January 2008 following the cyber attacks in Estonia. ${ }^{33}$ Since 2000, NATO has created several agencies for cyber defense.

31 NATO, Assured security: dynamic engagement, 40.

32 Jeffrey Hunker, "Cyber War and Cyber Power: Issues for NATO Doctrine," NATO Defense College Research Paper No. 62 (Rome: NATO Defense College, November 2010), 3; available at http://www.europesworld.org/NewEnglish/Home_old/PartnerPosts/tabid/671/PostID/2030/language/en-US/Default.aspx.

33 NATO, "Defending Against Cyber Attacks," available at http://www.nato.int/cps/en/natolive/topics_49193.htm. 
The first agency was the NATO Computer Incident Response Capability (NCIRC), established in 2002. Its main task is to report cyber security incidents and disseminate incident-related information to security management and users. It is part of the NATO Communications and Information Services Agency. The second is the Cooperative Cyber Defense Center of Excellence (CCDCOE), based in Tallinn. It was created in 2003 and is supported by the NATO Science Program. The core function of this center is research and training on cyber warfare. The CCDCOE, which was accredited as a NATO Center of Excellence (COE) in 2008, conducts research and training on cyber warfare and includes a staff of thirty specialists from sponsoring countries. The third is the Cyber Management Authority (CDMA), which is responsible for coordinating cyber defense within NATO. The latest agency, the Emerging Security Challenges Division (ESCD) was established in 2010 in order to address non-traditional threats, including cyber defense. ${ }^{34}$ Since 2002, NATO has approved several documents, such as the Cyber Defense Program, which have been supplemented in each summit until Lisbon. The main goal of the Program has been defense against cyber attacks by improving Alliance capabilities.

It is clear that the level of reliance on computers and informatics networks in NATO is so high that even a short and limited interruption of command and control communications could have a catastrophic impact on NATO operations, including a loss of human lives. It is necessary to find a way, in terms of military assets, to improve the capability to prevent those kinds of threats. Moreover, the threat from cyber attack to non-military and non-governmental networks is even higher, due to the fact that they are much less secure.

In November 2010, WikiLeaks released secret U.S. documents about the wars in Iraq and Afghanistan. The release included thousands of pages of classified reports and analysis with very sensitive information. ${ }^{35}$ This information directly hampered NATO's military operations in these states, and had an unprecedented impact on future operations and the security of troops, as well as some citizens in those countries that had collaborated with NATO. It was just one more example of how important it is to defend military communication systems and computers in order to protect troops in the field and domestic citizens and authorities who collaborate with coalition forces. The latest example, when WikiLeaks issued controversial U.S. diplomatic cables, has warned NATO authorities to take cyber attacks more seriously. The hacker attacks on banks during December 2010, as a reaction to the investigation of the founder of WikiLeaks, also showed us how vulnerable and unprepared civil institutions are.

\footnotetext{
34 Hunker, "Cyber War and Cyber Power," 9.

35 New York Times, "WikiLeaks" (11 February 2011); available at http://topics.nytimes. com/top/reference/timestopics/organizations/w/wikileaks/index.html
} 
The Internet can be used to disrupt both the military command and control structures of an enemy and wide-ranging areas of civilian life in the society of the country concerned. In the next few years, a comprehensive security policy will have to make more significant provisions for investment in the security of not only the military, but also the civilian communication structures of the Internet, so as to protect it from deliberate acts of disruption. One thing is clear from the above enumeration of threats: the vulnerability of civilian societies, including the armed forces, has drastically increased. As Anders Fogh Rasmussen noted, "Our societies have become totally reliant on information technology, and the cyber threat against critical infrastructure in all our nations is growing every day. There are millions of cyber attacks every day, targeting banking systems, air traffic control, government services, and power grids. Those are systems we depend on - and which we have to protect. These are all transnational problems, and they require multinational solutions. NATO is the preeminent multilateral security organization. Which means the Alliance can and must make a real contribution. And we are adapting to do just that." ${ }^{36}$

In the new SC, NATO recognized that cyber attacks are a rising threat to the security of the Alliance. What is worse, this threat is closely interconnected with energy security in terms of control over elements of the energy infrastructure through informatics networks. According to the recommendations of the group of experts on a new SC, "CCDCOE in Tallinn should do more through training to help members improve their cyber defence capability programmes." ${ }^{37}$ There is also a need for further contributions from all member states and broader cooperation, bearing in mind the complexity of the issue and cost effectiveness.

Defending against cyber attacks is not about military assets. It is more about other responses, such as intellectual and human capital. NATO's effort to deal with cyber threats was one of the key issues identified in advance of the Summit. One concern is the potential role of industry in promoting expensive solutions, especially as key defense companies are known to be realigning their structures to profit from a new wave of intelligence, cyber threats, and electronic weaponry. ${ }^{38}$

It is very difficult to predict what the consequences will be for member states and the Alliance from a future successful cyber attack. In the new era of asymmetric threats, it is legitimate to ask whether NATO's responsibilities should be extended beyond the sphere of traditional military security. The Alliance has made more progress in recent years in two mostly non-military areas of security: defense against cyber attacks and energy security. The agreements reached in these areas have established

36 Anders Fogh Rasmussen, Secretary-General of NATO, “The Strategic Concept and the Way Forward," keynote address to the participants of the Lisbon Summit, 20 November 2010; available at http://www.nato.int/cps/en/natolive/opinions_68499.htm.

37 NATO, Assured Security, Dynamic Engagement, 45.

38 NATO WATCH, "An Evaluation of the Lisbon Summit," 14. 
a framework for Alliance policy for the short to medium term and have prepared the groundwork for handling these issues in the context of the new strategy. NATO's policy in the cyber arena has evolved from the decision at the Riga Summit in 2006 to focus on protecting NATO infrastructure to a cyber defense policy agreed on in Bucharest in 2008. The Allies have decided that cyber attacks against members would be regarded as an Article IV matter. ${ }^{39}$

Given these steps taken, what has been achieved? Analyzing the doctrine and the agencies mentioned above that have been established in order to prevent cyber attacks, we can say that to some extent NATO has responded to the cyber threat. Regarding the complexity of the threat and the importance of coordination and collaboration, NATO declared that there has to be a two-way approach to the cyber issue. Exchanging information and experiences in this field is crucial, especially due to the fact that some NATO countries rated the "cyber threat" very high in their individual national security policies and deal with it at the national level in a much more concerted way than NATO does. Some NATO member states have recognized the threat posed by cyber attacks on critical infrastructures for over ten years. According to the U.K. National Security Strategy, cyber attacks have been established as a threat second only to terrorism in priority.

This approach is very pragmatic because it is difficult to predict which sector of society would be the target of a cyber attack. The victim of a cyber attack will most likely not be a site that is among the best defended, like a defense ministry or intelligence service, but rather a site that offers public services, such as a bank, air traffic control center, or some other government site. In other words, digital infrastructures are strategic assets in each country, and they are now at high risk if they are not properly protected. In the new digital and informatics age, any institution connected to informatics networks is not immune to attack. There are no borders between states regarding the cyber threat.

The first priority for NATO is to defend its own system, detect an attack, provide early warning, and recover after an attack. This also includes, for instance, operation networks for ISAF in Afghanistan. The second priority is to protect confidential information, which includes staff training, in order to prevent leaking information through USBs and computers within NATO. Assistance to member states includes support in order to protect military networks and critical national infrastructure. A high level of cooperation among NATO member states is necessary for success. It is good to deal with cyber attacks at the national level, but further effective measures at the international level are crucial for a common approach to cyber defense. It is important to highlight the fact that is difficult to find out who is behind a cyber attack. It could be one individual, a criminal organization, a non-state actor, or even a state.

39 "NATO Agrees to a Common Approach to Cyber Defence," EurActiv.com (4 April 2008); available at http://www.euractiv.com/en/infosociety/nato-agrees-common-approach-cyber-defence/article-171377. 


\section{Energy Security}

Given the close links between energy supply and the security of NATO, it is not surprising that energy security has become an issue for discussion within the Alliance. NATO has a responsibility to discuss any subject that concerns the Allies, and as the European member states certainly have a higher dependency than others on imports of natural gas, it is only natural that they should wish to raise this issue in NATO. ${ }^{40}$

According to the new Strategic Concept, "All countries are increasingly reliant on the vital communication, transport and transit routes on which international trade, energy security and prosperity depend. ... Some NATO countries will become more dependent on foreign energy suppliers and in some cases, on foreign energy supply and distribution networks for their energy needs. As a larger share of world consumption is transported across the globe, energy supplies are increasingly exposed to disruption. ... NATO will develop the capacity to contribute to energy security, including protection of critical energy infrastructure and transit areas and lines, cooperation with partners, and consultations among Allies on the basis of strategic assessments and contingency planning." ${ }^{41}$

NATO cannot avoid discussing energy security. In other words, the Alliance plans to be engaged in some cases when NATO member countries are faced with a disruption of energy supply. This leads to a much more open and broad question: How far could NATO's commitment in this field go? NATO's energy security role has two intertwining roots. The first is its military focus, which reflects the need for NATO to plan and protect key energy supplies in order to maintain the stability and security of its member states and its own operational capacity. ${ }^{42}$

For this purpose, the NATO Pipeline Committee was originally established in 1956 in order to deal with energy supplies. It was renamed the NATO Petroleum Committee in March 2008 in order to have a wider role and responsibilities. The main activities of this body are related to NATO petroleum requirements and how they are met in times of peace, crisis, and conflict. ${ }^{43}$ This means that NATO is not new to the field of energy security; in fact, it has long understood that the sustained, reliable provision of energy supplies to missions is of high importance.

40 “NATO's Continuing Transformation, Energy Security: NATO's Potential Role," NATO Review (5 April 2011); available at http://www.nato.int/docu/review/2006/issue3/english/ special1.html.

41 North Atlantic Council, Strategic Concept, 4-5.

42 Andrew Monaghan, "Energy Security: NATO's Limited, Complementary Role," NATO Defense College Research Paper, No. 36 (Rome: NATO Defense College, May 2008), 1-2.

43 NATO, "Petroleum Committee," available at http://www.nato.int/cps/en/natolive/topics_56706.htm. 
Ensuring a secure supply to missions in the field is clearly the highest priority goal in this area of concern. The best example is the challenge that NATO has been facing in its mission in Afghanistan. This operation requires enormous energy supplies with limited routes and infrastructure. Terrorist and insurgent attacks on the convoy make the situation on the ground even worse. In 2010, supply convoys travelling through Pakistan to ISAF bases in Afghanistan came under increasing attack by the Taliban and associated networks of militants. Following Pakistan's decision to block the strategic Khyber Pass route, such convoys that were already facing serious difficulties in making the trip now face even bigger security threats. ${ }^{44}$

These problems require intelligence sharing, sufficient troops to protect convoys, and alternative transport routes. NATO's agreement with Russia about air and land routes through its territory for logistic transports is one big step forward in sustaining NATO's operation in Afghanistan. ${ }^{45}$ According to Klaus Wittmann, "NATO does not intend to take on tasks of other organizations, and will limit its own contribution to where it adds value, mainly in the protection of infrastructure and transport lines."46 Besides problems with Pakistan on the transport route, piracy and armed robbery threaten vital sea lines of communication and economic interests off the Horn of Africa and in the Gulf of Aden. NATO Operation Ocean Shield principally focuses on at-sea counter-piracy operations in order to protect vessels from pirate attacks. ${ }^{47}$ This operation is indirectly about energy security, as it helps to protect oil tankers as they pass through the Gulf.

The new Strategic Concept has not clarified NATO's mission and capabilities to assist its members in energy security. A NATO plan would define its role in maintaining secure energy supplies with its capabilities and the roles of other organizations such as the EU and IEA. The role of NATO should include critical energy infrastructure protection, consequence management and, together with the EU and through the Partnership for Peace (PfP), support for international cooperation on energy security. ${ }^{48}$

44 "Question Raised over Responsibility for NATO Fuel Convoy Attacks," Strategic Discourse (16 October 2010); available at http://strategic-discourse.com/2010/10/questionsraised-over-responsibility-for-nato-fuel-convoy-attacks/.

45 NATO, Lisbon Summit Declaration, 6.

46 Klaus Wittmann, "NATO's New Strategic Concept, an Illustrative Draft" (September 2010), 5; available at http://www.johannes-varwick.de/rauf/wittmann-nato-strategic-concept-illustrative-draft.pdf.

47 NATO, "NATO Operation Ocean Shield," available at http://www.nato.int/cps/en/natolive/topics_48815.htm.

48 Hans Binnendijk and Geoffrey Hoon, "Affordable Defense Capabilities for Future NATO Missions," U.S. National Defense University Special Report (Washington, D.C.: Center for Technology and National Security Policy, February 2010), 9. 
Energy security can trigger conflict due to the fact that it is closely connected to national security ${ }^{49}$ As Daniel Moran and James Russell note, "The possibility that access to energy resources may become an object of large-scale armed struggle is almost incontestably the single most alarming prospect facing the international system today." ${ }^{50}$ According to the former Secretary-General of NATO, Javier Solana, "Energy security is also framed in geopolitical terms; NATO's primary preoccupation is how to protect the security of oil supplies to Western countries and to prevent the control over supplies by Russia from being used as a political lever."'51

Access to sufficient supplies of energy is a requirement for any modern state. However, most countries are dependent on external energy sources and on the means of delivering needed supplies via pipelines or shipping. Any substantial or sudden interruption of supplies to a NATO member state would be of concern, especially if the interruption were caused by the sabotage of energy infrastructure or by unlawful interference with maritime commerce. Such an occurrence, if prolonged, could lead to consultations under Article IV of the North Atlantic Treaty and to a determination by the Allies of an appropriate response. As a general matter, energy policy is a domestic issue, with the EU and the International Energy Agency offering services at the multinational level related to potential energy supply disruptions. NATO has an obligation to protect its own energy reserves in order to ensure the capability of its forces. ${ }^{52}$ Indeed, many terrorist attacks on energy facilities increase the risk.

Most Western countries are heavily dependent on the import of energy and are concerned about the security of energy supply. As Zurab Khamashuridze writes, "Energy scarcity and the inability of energy producing countries to increase exploration and extraction capacities creates additional tensions on the energy market and even causes friction between states in their efforts to secure energy resources. Aging energy infrastructures in some producer countries, combined with political instability and the increasing tendency of energy producing states to use their export potential for political leverage are additional sources of concern for European consumers. ${ }^{, 53}$ The threats to energy infrastructures have increased in the last decade due to the fact that terrorist organizations have identified vulnerabilities and exploited them. Furthermore, pirate attacks on ships in some chokepoints have increased the level of insecurity on maritime routes.

49 Monaghan, "NATO's Limited, Complementary Role," 2.

50 Daniel Moran and James A. Russell, "The Militarization of Energy Security," Strategic Insights 7:1 (February 2008): 2.

51 “Time for a Human Approach," ISN (Zurich), 17 November 2010; available at http:// www.isn.ethz.ch/isn/Current-Affairs/ISN-Insights/Detail?lng=en\&id=124018\&conte xtid734=124018\&contextid735=124014\&tabid $=124014$.

52 NATO, Assured security: dynamic engagement, 46.

53 Zurab Khamashuridze, "Energy Security and NATO - Any Role for the Alliance," Connections, The Quarterly Journal 7:4 (Fall 2008): 43. 
Aside from the protection of routes and providing supplies for NATO's troops, there is another aspect of energy security for NATO. The second issue focuses on political threats to energy security, and came to prominence in NATO following the Ukraine-Gazprom gas dispute of early January 2006 and later in 2009. ${ }^{54}$ According to Jaap de Hoop Scheffer, "For reasons that are obvious-including the potential of terrorists targeting our energy supplies - it makes sense to me that the allies should discuss this issue." ${ }^{5}$ Moreover, NATO did not have a solution during one of the worst crises, when almost all European countries suffered the consequences of Russian and Ukrainian disputes over natural gas in 2009. Is this a threat in terms of energy security for European NATO members? What implications would it have in the future, bearing in mind the fact that oil reserves are rapidly decreasing? The protection of infrastructure and transport lines, including pipelines, in the territory of countries that are not in the Alliance is a very controversial question. Is this a task for NATO military forces?

Increasing demand for energy resources, especially in countries such as China and India, and rising prices for gas and oil have put energy security issues at the top of NATO's agenda. Recent developments and debate about new pipelines have showed that energy issues are assuming increasing geostrategic importance, and have become an integral part of the foreign policy of some producer countries. ${ }^{56}$ According to Susanne Peters, "World energy markets are not liberalized. Rather, there is a trend toward energy-renationalization. Western oil companies only have full access to 6 percent of the world's known reserves. They can invest in an additional 11 percent of reserves through joint ventures and production sharing arrangements. But the rest of the world is closed to them." ${ }^{57}$ Energy security will remain a concern for the Alliance, but its future role in this issue is questionable. ${ }^{58}$ Although energy security is one of the major issues for member countries, the role of NATO in energy security is very limited and ambiguous. Energy security is much more about each of the member states and their individual energy policies.

54 Monaghan, “Energy Security: NATO’s Limited, Complementary Role," 2.

55 Jaap de Hoop Scheffer, Secretary-General of NATO, speech at the $42^{\text {nd }}$ Munich Security Conference, 12 February 2006; available at http://www.nato.int/docu/speech/2007/ index.html\#jan.

56 Khamashuridze, "Energy Security and NATO," 44.

57 Susanne Peters, "The Future Energy Security Environment: No Alternative to a Radical Shift," Energy Security and Security Policy, Research Department (Oberammergau: NATO School, November 2007): 84.

58 Jamie Shea, "NATO's Continuing Transformation, Energy Security: NATO's Potential Role," NATO Review (Autumn 2006); available at http://www.nato.int/docu/review/2006/ issue3/english/special1.html. 


\section{Conclusions}

Alliance theory suggests that the necessary preconditions for a security alliance include: compatible views on threats, shared interests, capabilities, and political will. There are many differences between the NATO member states when it comes to addressing the main threats. Some of the European countries are still considering territorial defense as one of the fields in which NATO should do more in terms of military exercises and training. Their aim is to verify capabilities and improve coordination within NATO. The U.S. points out the necessity for placing an emphasis on counterterrorism, missile defense, and prevention of WMD proliferation. For some Western European states, energy security is one of the key issues. A different notion of threats among member states is a significant obstacle to cohesion in the Alliance.

The fact that non-military and unconventional threats require non-military responses does not necessarily mean the absence of the military from efforts to address them. Close coordination and collaboration between the military and non-military organizations is a key to succeed in today's complex operational environment. The question of funding is still one of the highest concerns. NATO has launched a transformation effort in a time of severe economic crisis, when the majority of European state governments are attempting to reduce military spending and devote resources to other priorities. This may be one of the biggest obstacles to a successful transformation, which will (as is always the case when it comes to the military) require significant financial resources. Therefore, the NATO Secretary-General emphasized that the transformation process must begin with a well thought out strategy that will guarantee ultimate success: "NATO will be more effective by investing in modern capabilities to meet modern needs. We are investing in key capabilities, including cyber and missile defense. This is part of a broader process of reform that we will give a boost here in Lisbon. It is all about cutting fat and building muscle - eliminating what we no longer need, and investing where our real needs lie. That applies to NATO countries. It also applies to NATO as an organization. ... [W] ] will take forward fundamental reform of the NATO Command Structure, the NATO Agencies and our Headquarters in Brussels. Even though NATO is sixty-one years old, we will slim down, speed up and become more flexible." ${ }^{59}$ NATO's new Strategic Concept addresses a wide range of challenges and threats, starting from the proliferation of WMD and terrorism to climate change (the list is endless). A clear prioritization of threats is something that is missing within the new SC. It is very difficult to put those threats in the right order, satisfy each member state, and provide adequate funding for the development of new military capabilities.

59 Anders Fogh Rasmussen, Secretary-General of NATO, "The Strategic Concept and the Way Forward," keynote addressed to the participants of the Lisbon Summit, 20 November 2010; available at http://www.nato.int/cps/en/natolive/opinions_68499.htm. 
This will not be the first time that the Alliance agrees at the highest level during a summit, but afterwards many members fail to fulfill their obligations. The most notable example of a gap between declaration and implementation is in defense budget pledges. NATO member states' defense budgets are meant to be no lower than 2 percent of GDP, but in reality only a few NATO member countries meet such a requirement. This is not only a matter of percentage of GDP; the second issue is what purpose NATO countries are spending the money on (is it a modernization in the agreed direction, or for personnel and other purposes). A U.S. National Defense University Special Report notes, "Only three members of the Alliance are able to meet all four of the goals intended to give NATO the capabilities it needs to perform the missions assigned. Those four goals are to: devote two percent of GDP to defense spending; devote 20 percent of defense spending to investment; and maintain 50 percent of operational land forces deployable and 10 percent sustainable. Strong measures need to be taken at the Lisbon Summit to reinforce these goals and to halt the near free fall in defense spending Alliance-wide." ${ }^{\prime 60}$

The agreement about objectives in the Strategic Concept is only one step on the way towards the successful accomplishment of all of the important goals set forth there. However, the most important question that remains is how strategic political guidance will be implemented regarding the development of capabilities and their priority. A clear statement about priorities for NATO is not given in the Strategic Concept. This is one of the preconditions for success given the financial constraints that face the Alliance.

NATO understands that, in order to carry out its operations successfully, a global approach is required, especially in the sense of bringing all necessary resources together. The military factor is still very important, but the new tasks and missions it faces today also require other civilian forces to be included and engaged. It is extremely important for NATO to coordinate military and civilian actions and to cooperate with its partners. ${ }^{61}$ When it comes to the war in Afghanistan, the Europeans have lost all credibility in the United Sates' view, due to the lack of military capacity and will of some members. ${ }^{62}$ It is still difficult to gather and unify political support for providing sufficient resources for military operations. ${ }^{63}$

To sum up, the main issues for the Alliance are related to unconditional support for the development of new military capabilities in order to tackle non-traditional threats. New non-traditional threats require different responses and increased financing by member states. Alliance theory suggests that, for alliance cohesion and success,

60 Binnendijk and Hoon, “Affordable Defense Capabilities for Future NATO Missions,” 2.

61 Bardaji, "Prospects for a New NATO Strategic Concept," 2.

62 Ibid., 5.

63 Kamp, "The Way to NATO's New Strategic Concept," 4. 
member states need to have a common vision for responding to various threats. The objectives within the new Strategic Concept are not precise or clear enough to be able to steer the development of new capabilities. Regarding the fact that the perception of threats and challenges varies among member states, it is not likely that the ambitious objectives set forth in the new SC regarding the development of new military capabilities will be achieved in the foreseeable future. One additional constraint is the intentions of the EU to develop autonomous defense capabilities, which would inevitably lead to different approaches to some issues between the U.S. and some main EU member states.

NATO's raison d'être has been questioned since 1989, but the Alliance has somehow transformed itself and can still claim to be the most successful collective security arrangement in history. This article has provided insights into the gap between strategic threat identification and agreement over the need to build or adapt capabilities to meet these threats. To date, there is little indication that NATO is adapting existing or developing new military capabilities to address the new threats it has identified. This gap between ends and means will not entail the end of NATO, but rather settle the question of what kind of NATO will develop in the future. 


\section{Bibliography}

Bardaji, Rafael L.. Prospects for a New NATO Strategic Concept In Strategic Studies Group., 2007.

Binnendijk, Hans, and Geoffrey Hoon. Affordable Defense Capabilities for Future NATO Missions In U.S. National Defense University Special Report. Washington, D.C.: Center for Technology and National Security Policy, 2010.

Bush, George W.. Speech to a joint session of the U.S. Congress., 2001.

Defending Against Cyber Attacks. NATO, 2010.

Defense Against Terrorist Program. NATO, 2010.

Hunker, Jeffrey. Cyber War and Cyber Power: Issues for NATO Doctrine In NATO Defense College Research. Rome: NATO Defense College, 2010.

Kamp, Karl-Heinz. "Bush and the Future of NATO." Defense News (2005).

Kamp, Karl-Heinz. The Way to NATO's New Strategic Concept In NATO Defense College Research. Rome: NATO Defense College, 2009.

Khamashuridze, Zurab. "Energy Security and NATO: Any Role for the Alliance?" Connections: The Quarterly Journal 7, no. 4 (2008): 43-58.

Lisbon Summit Declaration. Lisbon: NATO, 2010.

Liska, George. Nations in Alliance. The Limits of Interdependence. Baltimore: Johns Hopkins University Press, 1962.

Monaghan, Andrew. Energy Security: NATO's Limited, Complementary Role In NATO Defense College Research. Rome: NATO Defense College, 2008.

Moran, Daniel, and James A. Russell. "The Militarization of Energy Security." Strategic Insights 7, no. 1 (2008): 2.

NATO 2020: Assured Security, Dynamic Engagement In Analysis and recommendations of the group of experts on a new strategic concept for NATO. Brussels: NATO, 2010.

NATO Agrees to a Common Approach to Cyber Defence. EurActiv.com, 2008.

NATO Reform Lite: An Evaluation of the Lisbon Summit In Briefing Paper. Lisbon: NATO WATCH, 2010.

NATO's Continuing Transformation, Energy Security: NATO's Potential Role. NATO Review, 2011.

NATO's Military Concept Against Terrorism. NATO, 2010. 
New NATO Division to Deal with Emerging Security Challenges. NATO, 2010. New Strategic Concept FAQs. NATO, 2010.

Question Raised over Responsibility for NATO Fuel Convoy Attacks In Strategic Discourse., 2010.

Rasmussen, Anders Fogh. The Strategic Concept and the Way Forward In keynote address to the participants of the Lisbon Summit., 2010.

Ringsmose, Jens, and Sten Rynning. Come Home, NATO? The Atlantic Alliance's New Strategic Concept. Copenhagen: Danish Institute for International Studies, 2007.

Robertson, Lord. Secretary-General of NATO, speech at NATO Headquarters., 2001.

Scheffer, Jaap de Hoop. Beyond the Bucharest Summit In speech delivered. Brussels: Secretary-General of NATO, 2008.

Scheffer, Jaap de Hoop. Secretary-General of NATO speech at Institute for National Security Studies and Atlantic Forum of Israel, Tel Aviv., 2009.

Scheffer, Jaap de Hoop. Secretary-General of NATO, speech at the 42nd Munich Security Conference., 2006.

Sireci, Jonathan, and Damon Coletta. "NATO's Realist Foundation, Enduring without an Enemy." Perspectives, Central European Review of International Affairs 17, no. 157 (2009): 57.

Strategic Concept-Active Engagement, Modern Defence. Lisbon: NATO, North Atlantic Council, 2010.

Susanne, Peters. "The Future Energy Security Environment: No Alternative to a Radical Shift." In Energy Security and Security Policy: NATO and the Role of International Security Actors . Kent State University, Geneva, 2004.

The NATO Strategic Concept and Evolution of NATO In Assembly of the Western European Union. Paris: Defense Committee of the Western European Union, 2010.

The Prague Summit and NATO's Transformation. Brussels: NATO Public Diplomacy Division, 2003.

Time for a Human Approach. Zurich: ISN, 2010.

Walt, Stephen M.. The Origins of Alliances. Ithaca, NY: Cornell University Press, 1990. 
Wight, Martin. Power Politics. New York: Holmes \& Maier, 1978.

WikiLeaks. New York Times (2011).

Wittmann, Klaus. NATO's New Strategic Concept, an Illustrative Draft., 2010. 